\title{
NRAS Exon 4 Mutation
}

National Cancer Institute

\section{Source}

National Cancer Institute. NRAS Exon 4 Mutation. NCI Thesaurus. Code C135720.

A molecular genetic abnormality indicating the presence of a mutation in exon 4 of the NRAS gene. 